\title{
Influence of Canopy Interception of Soybean and Corn on Water Distribution of Center Pivot Sprinkling Machine
}

\author{
Hua $\mathrm{Cao}^{1,2}$, Yongshen $\mathrm{Fan}^{1}$, Zhen Chen ${ }^{1}$, Xiuqiao Huang ${ }^{1 *}$ \\ ${ }^{1}$ Farmland Irrigation Research Institute, Chinese Academy of Agricultural Sciences, Xinxiang 453002, China \\ ${ }^{2}$ Graduate School of Chinese Academy of Agricultural Sciences, Beijing 100081, China
}

Corresponding Author Email: huangxiuqiao@caas.cn

https://doi.org/10.18280/jesa.530108

Received: 10 July 2019

Accepted: 3 November 2019

\section{Keywords:}

Center pivot sprinkling machine (CPSM), canopy interception, water distribution, sprinkler uniformity, soybean, corn

\begin{abstract}
This paper aims to disclose the variation in water distribution and sprinkler uniformity after the canopy interception of soybean and corn. Firstly, the change laws of the water distribution and sprinkler uniformity were tested on an open field with a center pivot sprinkling machine (CPSM) operating at different speeds. Next, the intercepted water volume, the water distribution and sprinkler uniformity of the CPSM were measured at two water-needing growth stages of each crop. The results show that: On the open field, the irrigation depth of the CPSM has an approximately exponential relationship with the operating speed. The mean circumferential sprinkler uniformities were greater than the mean radial sprinkler uniformities at the same operating speeds. When the CPSM operated at $100 \%$ speed, the sprinkler uniformity at the flowering stage of soybean was $2.37 \%$ higher than that on the open field, and $2.88 \%$ higher than that at the branching stage of soybean. When the CPSM operated at $100 \%$ speed, the sprinkler uniformities at the jointing and heading stages of corn were both significantly lower than those on the open field. The sprinkler uniformity after canopy interception provides an evaluation criterion for the effect of fertilizer or pesticide application.
\end{abstract}

\section{INTRODUCTION}

Since the implementation of rural land circulation, agricultural mechanization has been well received by Chinese farmers [1]. The mechanized operations can effectively reduce labor cost and enhance crop yield and quality. With the rise of labor cost, mechanization is the inevitable trend of agricultural development in China [2]. Northeast China, a collective name for the three northeastern provinces (Liaoning, Jilin and Heilongjiang), provides a good portion of farmlands in the country. The agricultural practice in this region is highly mechanized.

In recent years, there is a campaign to save water and boost yield. As a result, many farmers of Heilongjiang Province have turned to sprinkler irrigation to reduce the water volume consumed in the irrigation of dry farmlands. The most widely used sprinkling machines include center pivot sprinkling machine (CPSM) and reel sprinkling machine (RSM) [3]. Each CPSM can irrigate a wide area of farmland in a short time, and save lots of labor due to the high degree of automation. Therefore, the CPSM is very suitable for Northeast China, a main producing area of soybean and corn [4].

The existing studies on sprinkling machines focus on the hydraulic performance [5-8], failing to explore deep into the relationship between sprinkler irrigation and canopy interception. Similar to natural rainfall, the sprinkled water can be intercepted by crops. The loss induced by canopy interception greatly suppresses the water volume in the field. To improve irrigation efficiency, it is necessary to cut down the loss resulted from canopy interception [9]. After canopy interception, the distribution of sprinkled water is mainly affected by water volume, sprinkling intensity and leaf area index (LAI) [10].

The previous research of canopy interception mainly tackles the impact of rainfall on canopy interception of plants [11-13]. Many scholars [14-17] proved that the water loss of forest ecosystem is partially attributable to the rainfall loss caused by canopy interception and the subsequent atmospheric evaporation. From the angles of water distribution and canopy structure, Li et al. [18] discussed the water distributions on spring corns above and below the canopy at different growth stages. Li and Rao [19] examined the effects of sprinkler irrigation on the distribution of sprinkled water after being intercepted by the canopy of winter wheat. Kang et al. [20] conducted field experiments on canopy interception of winter wheat. Liu et al. [21] determined the relationship between the number of stem flows, plant growth and rainfall. Wang et al. [22] designed a novel method to measure the water volume intercepted by the canopy of winter wheat under sprinkler irrigation. Through field experiments, Wang et al. [23] explored how corn canopy affects the distribution of sprinkled water. Mauch et al. [24] introduced a new method to measure canopy water retention. Liu et al. [25] tested and analyzed the maximum canopy interception of crops like soybean, corn, and alfalfa.

So far, there is no report on how canopy interception of crops affects sprinkler uniformity, a determinant of crop yield. To disclose the impact of canopy interception on sprinkled water distribution, this paper carries out sprinkler irrigation of soybean and corn with a CPSM moving at different speeds, and measures the sprinkler uniformity and water distribution at two water-needing growth stages of each crop. On this basis, 
the authors discussed how the canopy interception of the two crops affects the sprinkler uniformity and water distribution.

\section{MATERIALS AND METHODS}

\subsection{Test site and CPSM design}

Our tests were conducted in Helongjiang Hydraulic Experiment and Research Center (N: 45'38'36'; E: $\left.126^{\circ} 22^{\prime} 38^{\prime \prime}\right)$, which is affiliated to Heilongjiang Provincial Hydraulic Research Institute (HHR). The Center is located on Airport Road, Daoli District, Harbin, the seat of Heilongjiang Province. The altitude of the test site is $152 \mathrm{~m}$.

As shown in Figure 1, the CPSM used in our tests is $90 \mathrm{~m}$ in length, including a $40.5 \mathrm{~m}$-long first span, a $40.5 \mathrm{~m}$-long second span and a 9m-long third span. The third span is an arm with a spray gun (sprinkling width: $25 \mathrm{~m}$ ) at the tail. Overall, the CPSM can irrigate the field within the radius of $115 \mathrm{~m}$.

A total of 37 Nelson D3000 fixed-spray sprinklers are installed at an interval of $2.25 \mathrm{~m}$ on the CPSM at $1.5 \mathrm{~m}$ above the ground, all of which sprinkles the groundwater from motor-pumped wells. There are 16 sprinklers on the first span, 18 sprinklers on the second span, and 3 sprinklers on the third span. No sprinkler is installed on the first span at $2.25 \mathrm{~m}$ and $4.5 \mathrm{~m}$ from the center pivot.

Dongnong 67 soybean and Qiangsheng 377 corn were selected for our tests. Both crops were sowed by strip sowing. The row spacing, plant spacing and sowing depth were $20 \mathrm{~cm}$, $10 \mathrm{~cm}$ and $3 \mathrm{~cm}$ for soybean, and $66 \mathrm{~cm}, 25 \mathrm{~cm}$ and $5 \mathrm{~cm}$ for corn, respectively.

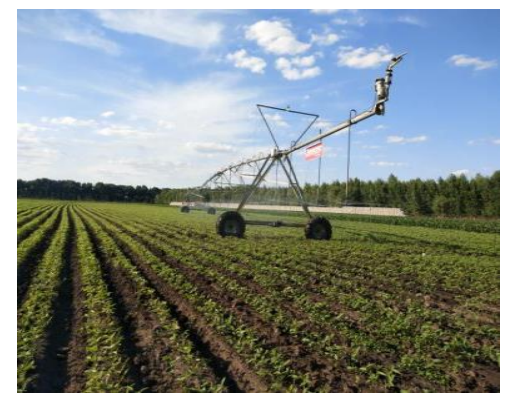

Figure 1. The operation of the CPSM

\subsection{Test design and field layout}

From May to August 2018, our tests were conducted at a low wind speed $(<3 \mathrm{~m} / \mathrm{s})$ in the hydraulic performance test area singled out from corn and soybean fields. The operating parameters of the CPSM were measured in the branching and flowering stages of soybean, and in the jointing and heading stages of corn, and used to evaluate the influence of canopy interception of the two crops on the water distribution and sprinkler uniformity of the CPSM.

During the branching stage of soybean and jointing stage of corn, the sprinkler uniformity of the CPSM after canopy interception of each crop was respectively tested at 10\%, 20\%, $30 \%, 40 \%, 50 \%, 60 \%, 70 \%, 80 \%, 90 \%$ and $100 \%$ of the operating speed of the CPSM. During the flowering stage of soybean and heading stage of corn, the sprinkler uniformity of the CPSM after canopy interception of each crop was tested at $100 \%$ of the operating speed of the CPSM.

As shown in Figure 2, a total of 191 rain gauges are deployed at an interval of $2 \mathrm{~m}$ on the CPSM, including 165 along the radial direction and 26 along the circumferential direction, according to the Chinese national standard [26].

In the radial direction, the 165 rain gauges are evenly arranged in three rows, i.e. 55 rain gauges in each row, in the light of the structural dimensions of the CPSM. Along the counterclockwise direction, the three rows are denoted as the first two, the second row and the third row. The distance from the center pivot to the innermost rain gauge in the first row is $0.67 \mathrm{~m}$ longer than that in the second row, and $1.34 \mathrm{~m}$ longer than that in the third row. The straight line between the outermost rain gauges in the first and second rows, and that between the outermost rain gauges in the second and third rows are both $17 \mathrm{~m}$, smaller than the upper limit of $50 \mathrm{~m}$ specified in the Chinese national standard [26].

In the circumferential direction, the 26 rain gauges are deployed in three arcs: 4 on the $12 \mathrm{~m}$-long arc $38 \mathrm{~m}$ from the center pivot, 10 on the $24 \mathrm{~m}$-long arc $76 \mathrm{~m}$ from the center pivot, and 12 on the $28 \mathrm{~m}$-long arc $90 \mathrm{~m}$ from the center pivot.

In addition, three reference rain gauges (diameter: $88 \mathrm{~mm}$; height: $150 \mathrm{~mm}$ ) were placed at $200 \mathrm{~m}$ from the test field to measure the evaporation during the sprinkler irrigation. The microclimate at the locations of the reference rain gauges is not affected by the operation of the CPSM.

Before and after each test, the initial/final water volume in each rain gauge was measured. The measurement time of the rain gauges, i.e. the duration of sprinkler irrigation, was also recorded after each test. Then, the mean evaporation of the three reference rain gauges was computed, and used to correct the initial water volume of each rain gauge. For each rain gauge, the initial water volume was corrected as the sum of the final water volume and the mean evaporation during the sprinkler irrigation:

$$
\mathrm{V}_{\mathrm{i}}=\mathrm{V}_{\mathrm{ci}}+\mathrm{E}_{\mathrm{i}} \mathrm{t}_{\mathrm{i}}
$$

where, $V_{i}$ is the corrected initial water volume of each rain gauge $(\mathrm{mL}) ; V_{c i}$ is the final water volume of each rain gauge $(\mathrm{mL}) ; E_{i}$ is the mean evaporation of rain gauges per unit time during sprinkler irrigation $(\mathrm{mL} / \mathrm{min}) ; t_{i}$ is the duration of sprinkler irrigation ( $\mathrm{min})$.

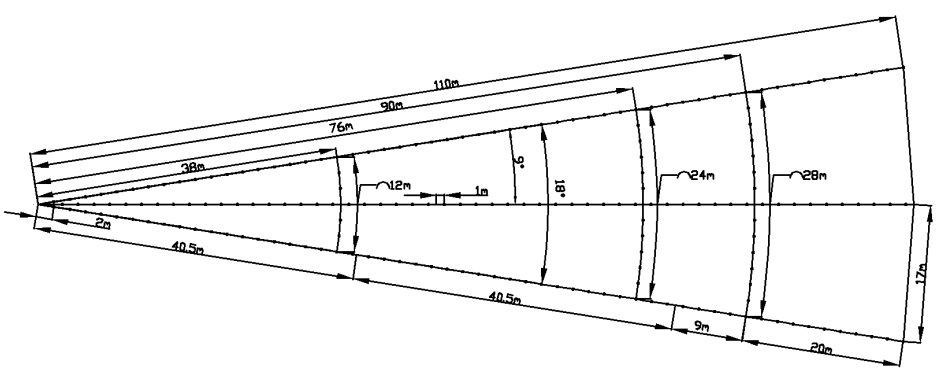

Figure 2. The layout of rain gauges 


\subsection{Calculation of sprinkler uniformity}

The sprinkler uniformity of the CPSM at different operating speeds can be computed by [26]:

$$
\mathrm{C}_{\mathrm{UH}}=100 \times\left[1-\frac{\sum_{\mathrm{i}=1}^{\mathrm{n}}\left|\mathrm{H}_{\mathrm{i}}-\overline{\mathrm{H}}_{\mathrm{w}}\right| \mathrm{D}_{\mathrm{i}}}{\sum_{\mathrm{i}=1}^{\mathrm{n}} \mathrm{H}_{\mathrm{i}} \mathrm{D}_{\mathrm{i}}}\right]
$$

where, $C_{U H}$ is the Herman-Hein coefficient of water distribution uniformity; $\mathrm{n}$ is the number of rain gauges; $i$ is the serial number of rain gauges $(i=1$ is the innermost rain gauge; $i=\mathrm{n}$ is the outermost rain gauge); $H_{i}$ is the water depth in the $i$ th rain gauge; $D_{i}$ is the distance of the $i$-th rain gauge to the center pivot; $\bar{H}_{W}$ is the weighted mean water depth in all rain gauges. by:

The water depth in in the $i$-th rain gauge can be computed

$$
\mathrm{H}_{\mathrm{i}}=\frac{\mathrm{V}_{\mathrm{i}}}{\pi \mathrm{R}^{2}}
$$

where, $V_{i}$ and $R$ are the volume and the radius of the $i$-th rain gauge.

The weighted mean water depth in all rain gauges can be computed by:

$$
\overline{\mathrm{H}}_{\mathrm{w}}=\frac{\sum_{\mathrm{i}=1}^{\mathrm{n}} \mathrm{H}_{\mathrm{i}} \mathrm{D}_{\mathrm{i}}}{\sum_{\mathrm{i}=1}^{\mathrm{n}} \mathrm{D}_{\mathrm{i}}}
$$

\section{HYDRAULIC PERFORMANCE ANALYSIS}

\subsection{Irrigation depth}

On an open field, the CPSM operated at different speeds (at $10 \%, 20 \%, 30 \%, 40 \%, 50 \%, 60 \%, 70 \%, 80 \%, 90 \%$ and $100 \%$ of the operating speed) with the spray gun disabled. Figure 3 shows the curve between the irrigation depth and operating speed. It can be seen that, as the operating speed increased from $10 \%$ to $100 \%$, the irrigation depth of the CPSM gradually decreased. The irrigation depth has an approximately exponential relationship with the operating speed. The irrigation depth $\mathrm{h}(\mathrm{mm})$ can be estimated from the operating speed by:

$$
\mathrm{h}=2.0477 \mathrm{v}^{-0.933}\left(\mathrm{R}^{2}=0.9927\right)
$$

where, $v$ is the operating speed of the CPSM (\%).

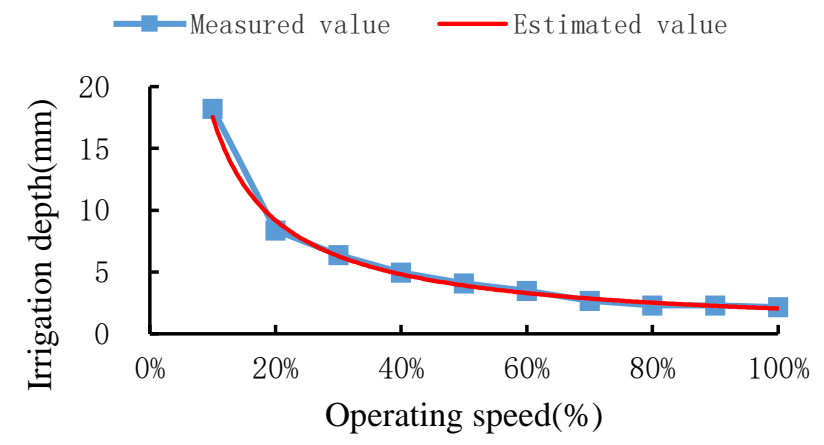

Figure 3. Irrigation depths at different operating speeds

\subsection{Radial water distribution}

Water leakage was observed during the test, due to the aging of the rubber ring on the flange at the branch connection $(81 \mathrm{~m}$ from the center pivot) between the second and third rows. Besides, no sprinkler is installed on the first span at $2.25 \mathrm{~m}$ and $4.5 \mathrm{~m}$ from the center pivot.

For the universality of data, the water depths of the rain gauges at $10-70 \mathrm{~m}$ from the center pivot were selected to further analyze the radial water distribution at different operating speeds. Figure 4 presents the irrigation depth of these rain gauges at $20 \%, 40 \%, 60 \%, 80 \%$ and $100 \%$ of operating speed. It can be seen that the irrigation depth at $20 \%$ of operating speed was far greater than that at other speeds, and the irrigation depth was the smallest at $10 \%$ of operating speed.

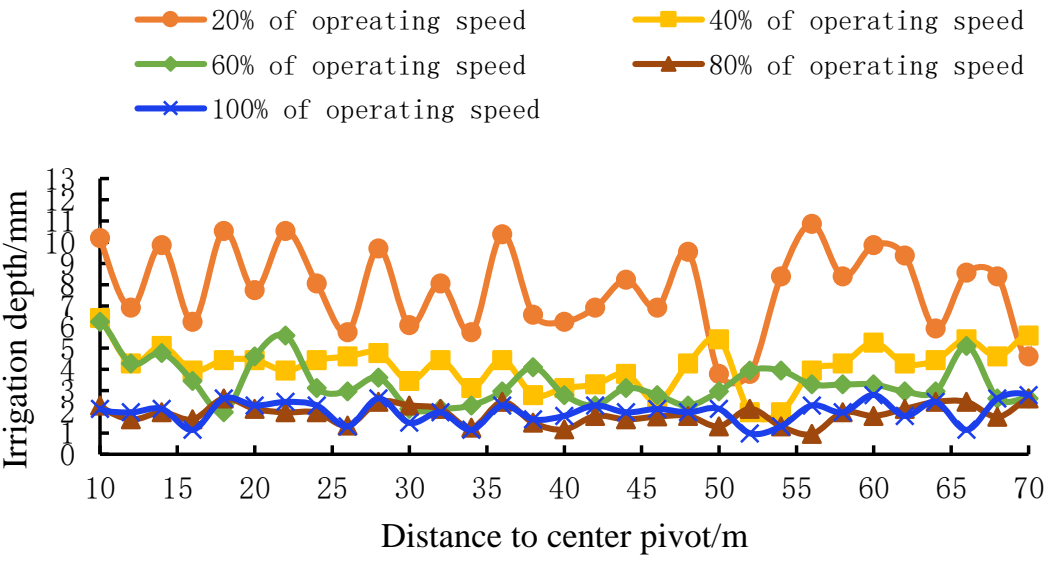

Figure 4. Radial water distributions at different operating speeds

Figure 5 is the histogram of the mean radial sprinkler uniformities of the first and second spans at different operating speeds. It can be seen that the maximum $(85.77 \%)$ and minimum $(76.80 \%)$ of radial sprinkler uniformity appeared at 
$10 \%$ and $80 \%$ of operating speed, respectively; with the growing operating speed, the mean sprinkler uniformity exhibited a declining trend; the mean radial sprinkler uniformity of the CPSM remained above $75 \%$.

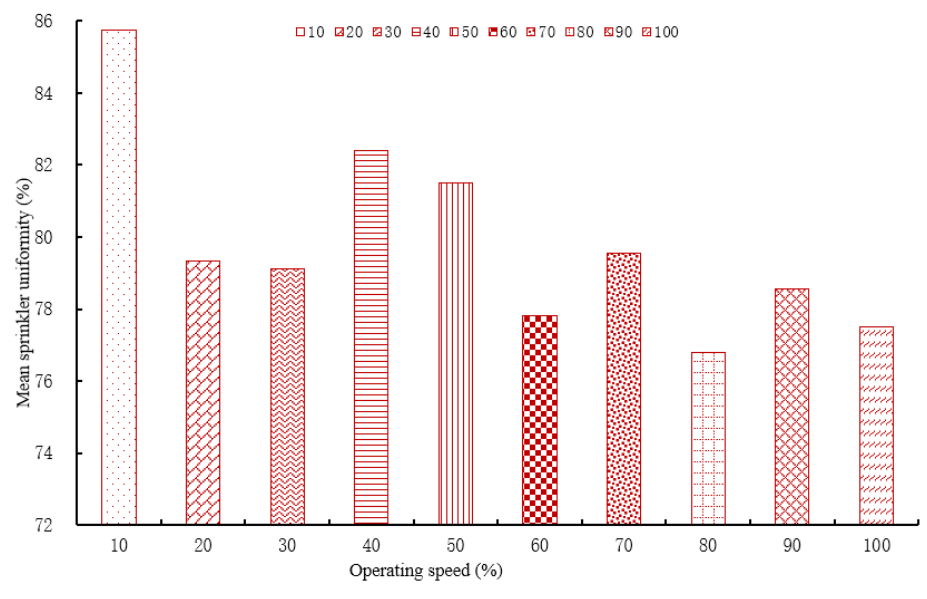

Figure 5. Mean radial sprinkler uniformities at different operating speeds

\subsection{Circumferential sprinkler uniformity}

The mean circumferential sprinkler uniformity of the CPSM was recorded in Table 1.

As shown in Table 1, the mean circumferential sprinkler uniformities of the rain gauges at $38 \mathrm{~m}, 76 \mathrm{~m}$ and $90 \mathrm{~m}$ from the center pivot were greater than $80 \%$ at three different operating speeds.

The data in Table 1 were subjected to one-way analysis of variance (one-way ANOVA) on SPSS. The results show a significant difference between the mean circumferential sprinkler uniformities at the three operating speeds. The largest mean circumferential sprinkler uniformity $(98.13 \%)$ was observed at $76 \mathrm{~m}$ from the center pivot, followed by that $(87.10 \%)$ at $38 \mathrm{~m}$ from the center pivot.

The mean circumferential sprinkler uniformities were greater than the mean radial sprinkler uniformities at the same operating speeds.

Table 1. The mean circumferential sprinkler uniformity of the CPSM

\begin{tabular}{|c|c|c|c|c|c|c|c|c|c|c|c|c|c|c|}
\hline \multirow[t]{2}{*}{ Dis* } & \multicolumn{10}{|c|}{ Mean sprinkler uniformity at different operating speeds/\% } & \multirow{2}{*}{$\begin{array}{l}\text { Standard } \\
\text { deviation }\end{array}$} & \multirow{2}{*}{$\begin{array}{l}\text { Standard } \\
\text { error }\end{array}$} & \multirow{2}{*}{$\begin{array}{c}\text { Variation } \\
\text { coefficient } / \%\end{array}$} & \multirow[t]{2}{*}{ Mean/\% } \\
\hline & 10 & 20 & 30 & 40 & 50 & 60 & 70 & 80 & 90 & 100 & & & & \\
\hline 38 & 80.22 & 80.99 & 88.88 & 80.34 & 90.32 & 94.00 & 91.73 & 91.85 & 77.51 & 95.17 & 6.60 & 2.09 & 7.58 & $87.10 \mathrm{a}$ \\
\hline 76 & 96.00 & 98.50 & 99.16 & 97.75 & 99.44 & 99.48 & 93.80 & 98.83 & 99.05 & 99.33 & 1.85 & 5.86 & 1.86 & $98.13 b$ \\
\hline 90 & 89.01 & 77.49 & 80.94 & 69.79 & 80.66 & 88.8 & 83.33 & 76.95 & 81.85 & 77.71 & 5.73 & 1.81 & 7.10 & $80.65 c$ \\
\hline
\end{tabular}

* Distance from rain gauge to center pivot $/ \mathrm{m}$

\section{INFLUENCE OF SOYBEAN CANOPY INTERCEPTION ON CPSM HYDRAULIC PERFORMANCE}

\subsection{The influence at branching stage}

Previous measurements put the mean plant height, mean leaf area and the LAI of soybean at $14.08 \mathrm{~cm}, 72.82 \mathrm{~cm}^{2}$ and $0.0749 \mathrm{~m}^{2} / \mathrm{m}^{2}$, respectively. The mean water depths of all rain gauges on the CPSM were calculated at $10 \%, 20 \%, 30 \%, 40 \%$, $50 \%, 60 \%, 70 \%, 80 \%, 90 \%$ and $100 \%$ of the operating speed, respectively. In addition, three reference rain gauges were placed on an open field not affected by the crop to capture the mean water depth without canopy interception. The water volume intercepted by the canopy was calculated by the water balance equation. The sprinkler uniformities and intercepted water volumes at different speeds are listed in Table 2 below.

Table 2. The sprinkler uniformities and intercepted water volumes at different speeds at the branching stage of soybean

\begin{tabular}{cccccc}
\hline $\begin{array}{c}\text { Operating } \\
\text { speed/\% }\end{array}$ & $\begin{array}{c}\text { Sprinkler uniformity } \\
\text { after canopy } \\
\text { interception/\% }\end{array}$ & $\begin{array}{c}\text { Mean water depth } \\
\text { of reference rain } \\
\text { gauges/mm }\end{array}$ & $\begin{array}{c}\text { Mean water depth of water } \\
\text { gauges after canopy } \\
\text { interception/mm }\end{array}$ & $\begin{array}{c}\text { Intercepted } \\
\text { water } \\
\text { volume/mm }\end{array}$ & $\begin{array}{c}\text { Percentage of } \\
\text { canopy } \\
\text { interception/\% }\end{array}$ \\
\hline 10 & 84.62 & 18.22 & 14.46 & 3.76 & 20.64 \\
20 & 78.01 & 8.38 & 6.94 & 1.44 & 17.21 \\
30 & 81.48 & 6.38 & 5.24 & 0.14 & 17.87 \\
40 & 82.34 & 4.96 & 4.34 & 0.46 & 12.49 \\
50 & 83.28 & 4.09 & 3.63 & 0.39 & 11.19 \\
60 & 70.85 & 3.48 & 3.09 & 0.26 & 11.16 \\
70 & 64.78 & 2.67 & 2.41 & 0.14 & 9.74 \\
80 & 76.28 & 2.31 & 2.17 & 0.08 & 6.06 \\
90 & 78.56 & 2.29 & 2.21 & 0.08 & 3.49 \\
100 & 77.86 & 2.16 & 2.08 & - & 3.7 \\
Mean & 77.81 & - & - & & - \\
\hline
\end{tabular}


As shown in Table 2, at the branching stage of soybean, the intercepted water volume and percentage of canopy interception decreased with the growth in the operating speed. After canopy interception, the mean sprinkler uniformity was $77.81 \%$ at the branching stage, $2.54 \%$ lower than that $(79 / 83 \%)$ on the open field. This means, at the branching stage of soybean, the sprinkled water was partially intercepted by the canopy before falling into the soil; the sprinkler uniformity was slightly lower than that in the absence of canopy.

The reason for the slight difference is as follows: During sprinkling irrigation, the water is partly retained by the canopy of soybeans, and partly falls into the open fields between plants. The retaining effect comes from the adhesion and adsorption of soybean leaves and stems. Meanwhile, the open fields are rather large between the plants, due to the small leaf area per plant at the branching stage.

\subsection{Influence at flowering stage}

At flowering stage, the mean plant height, mean leaf area and the LAI of soybean are $55.52 \mathrm{~cm}, 1,327.77 \mathrm{~cm}^{2}$ and $1.365 \mathrm{~m}^{2} / \mathrm{m}^{2}$, respectively. According to the water balance equation, the sprinkled water volume after canopy interception was $1.86 \mathrm{~mm}$, and the intercepted water volume was $0.3 \mathrm{~mm}$, which is $0.22 \mathrm{~mm}$ higher than the intercepted water volume at the branching stage. The soybean intercepted $13.89 \%$ of the total sprinkled water volume at the flowering stage.

The sprinkler uniformity at the flowering stage of soybean was only analyzed at $100 \%$ of the operating speed. Figure 6 provides the mean water depths of the CPSM rain gauges after canopy interception. It can be seen that, when the CPSM operated at $100 \%$ speed, the sprinkled water was distributed very uniformity after canopy interception. The sprinkler uniformity of the CPSM was computed as $79.34 \%$, which is $2.37 \%$ higher than that on the open field, and $2.88 \%$ higher than that at the branching stage of soybean.

The $2.37 \%$ difference can be explained as follows: At the flowering stage, the soybean leaves are highly differentiated. The LAI and plant height both reach the maximum. At this time, the soybean field is fully covered by the leaves and stems, leaving no open field. Thus, the sprinkled water is redistributed by the canopy before entering the soil [27].

The $2.88 \%$ difference is attributable to the following factors At the branching stage, the leaf area of each plant has not reached the maximum, and the LAI is relatively small. Despite the redistribution at the leaves and stems, a good portion of water directly falls into the soil. Hence, the sprinkler uniformity after canopy interception is greatly affected by the LAI of the crop [17]

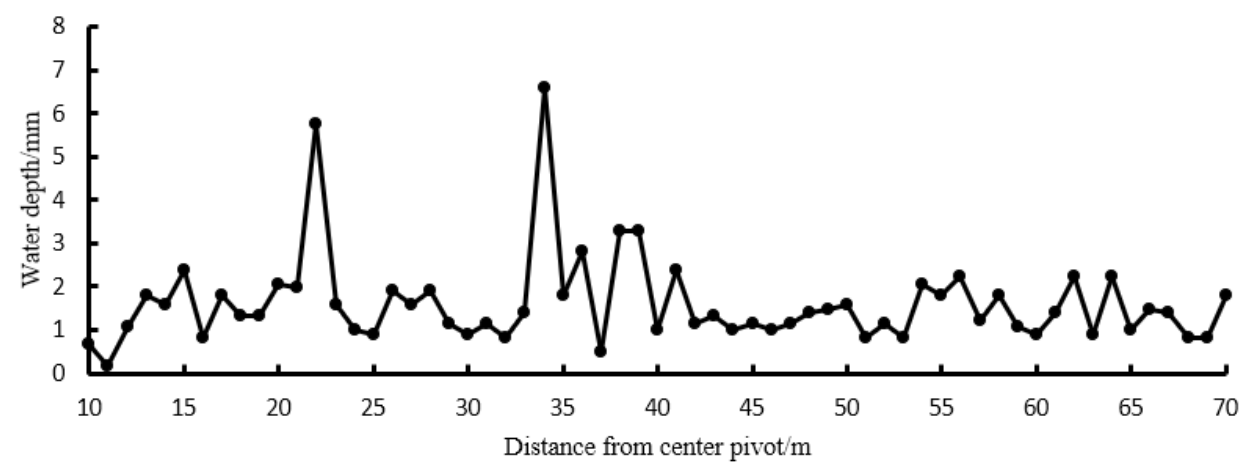

Figure 6. Water depths of rain gauges at $100 \%$ speed at the flowering stage of soybean

\section{INFLUENCE OF CORN CANOPY INTERCEPTION ON CPSM HYDRAULIC PERFORMANCE}

\subsection{Influence at jointing stage}

At the jointing stage, the stem base of the corn begins to elongate. Since then, the plants grow rapidly, especially in plant height and leaf area. The mean plant height, mean leaf area and the LAI of corn at the jointing stage are $798.03 \mathrm{~cm}^{2}$, $0.413 \mathrm{~m}^{2} / \mathrm{m}^{2}$, and $49.43 \mathrm{~cm}$. The CPSM hydraulic performance at the jointing stage of corn was measured under the same conditions as that at the branching stage of soybean. The sprinkler uniformities and intercepted water volumes at different speeds are listed in Table 3 below.

Table 3. The sprinkler uniformities and intercepted water volumes at different speeds at the jointing stage of corn

\begin{tabular}{|c|c|c|c|c|c|}
\hline $\begin{array}{l}\text { Operating } \\
\text { speed } / \%\end{array}$ & $\begin{array}{c}\text { Sprinkler uniformity } \\
\text { after canopy } \\
\text { interception } / \% \\
\end{array}$ & $\begin{array}{l}\text { Mean water depth } \\
\text { of reference rain } \\
\text { gauges } / \mathrm{mm} \\
\end{array}$ & $\begin{array}{c}\text { Mean water depth of water } \\
\text { gauges after canopy } \\
\text { interception/mm }\end{array}$ & $\begin{array}{l}\text { Intercepted } \\
\text { water } \\
\text { volume } / \mathbf{m m} \\
\end{array}$ & $\begin{array}{l}\text { Percentage of } \\
\text { canopy } \\
\text { interception } / \%\end{array}$ \\
\hline 10 & 76.98 & 18.22 & 13.02 & 5.2 & 28.54 \\
\hline 20 & 63.42 & 8.38 & 6.03 & 2.35 & 28.07 \\
\hline 30 & 73.44 & 6.38 & 5.63 & 0.75 & 11.76 \\
\hline 40 & 44.3 & 4.96 & 3.62 & 1.34 & 27 \\
\hline 50 & 49.79 & 4.09 & 2.49 & 1.6 & 39.08 \\
\hline 60 & 45.61 & 3.48 & 1.77 & 1.71 & 49.11 \\
\hline 70 & 41.18 & 2.67 & 2.02 & 0.65 & 24.34 \\
\hline 80 & 54.3 & 2.31 & 1.64 & 0.67 & 29 \\
\hline 90 & 48 & 2.29 & 1.74 & 0.55 & 24.02 \\
\hline 100 & 57.98 & 2.16 & 1.72 & 0.44 & 20.37 \\
\hline Mean & 55.5 & - & - & - & - \\
\hline
\end{tabular}


As shown in Table 3, at the jointing stage of corn, the sprinkler uniformity after canopy interception peaked at $76.98 \%$, when the operating speed was $10 \%$, and the mean sprinkler uniformity was $55.5 \%, 30.48 \%$ lower than that on the open field. The low sprinkler uniformity at the jointing stage of corn is resulted from the small LAI of corn at this stage. Most sprinkled water directly falls into the soil, and only a few are intercepted by the leaves and stems of corn before falling into the soil.

\subsection{Influence at heading stage}

At heading stage, the mean plant height, stem diameter, mean leaf area and the LAI of corn are $285.18 \mathrm{~cm}, 23.37 \mathrm{~mm}$, $7,709.47 \mathrm{~cm}^{2}$, and $7.925 \mathrm{~m}^{2} / \mathrm{m}^{2}$, respectively. It was computed that at the heading stage of corn, the sprinkled water volume after canopy interception was $0.52 \mathrm{~mm}$, and the intercepted water volume was $1.64 \mathrm{~mm}$, which is $1.20 \mathrm{~mm}$ higher than the intercepted water volume at the jointing stage. The corn intercepted $75.93 \%$ of the total sprinkled water volume at the heading stage.

The sprinkler uniformity at the heading stage of soybean was only analyzed at $100 \%$ of the operating speed. Figure 7 provides the mean water depths of the CPSM rain gauges after canopy interception.

As shown in Figure 7, at the heading stage, the water depth after canopy interception changed violently along the radial direction of the CPSM, exhibiting multiple peaks in water distribution. This is because the mean leaf area of corn reaches the maximum at the heading stage. Most sprinkled water is captured by corn leaves, and transmitted along the stems to the roots. Therefore, the rain cylinders close to the stem have deeper water than those below the leaves. That is why the sprinkler uniformity decreased significantly after the canopy interception of corn.

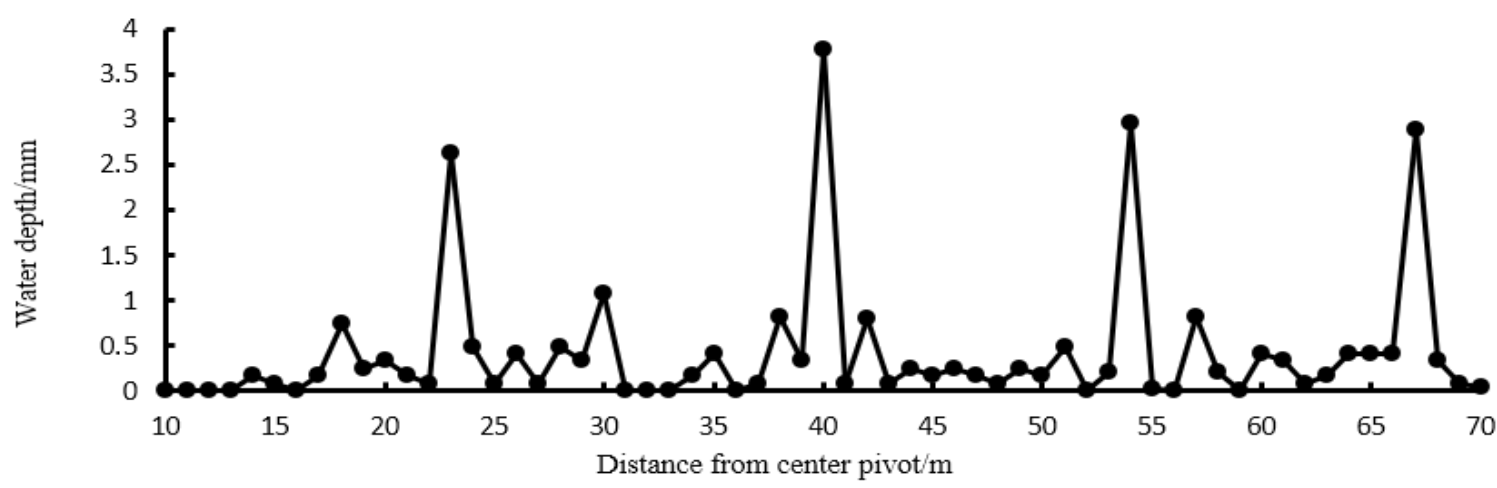

Figure 7. Water depths of rain gauges at $100 \%$ speed at the heading stage of corn

\section{CONCLUSIONS}

On the open field, the irrigation depth of the CPSM has an approximately exponential relationship with the operating speed. With the growing operating speed, the irrigation depth of the CPSM gradually decreased. As the operating speed increased from $10 \%$ to $100 \%$, the mean sprinkler uniformity exhibited a declining trend; the mean radial sprinkler uniformity of the CPSM remained above $75 \%$. The mean circumferential sprinkler uniformities were greater than the mean radial sprinkler uniformities at the same operating speeds, indicating that the sprinkled water is distributed more uniformly along the travel trajectory than along the branches.

The canopies of soybean and corn have different impacts on the sprinkler uniformity. Due to canopy interception, the sprinkler uniformity on soybean field was higher than that on open field: When the CPSM operated at $100 \%$ speed, the sprinkler uniformity at the flowering stage of soybean was $2.37 \%$ higher than that on the open field, and $2.88 \%$ higher than that at the branching stage of soybean. Due to canopy interception, the sprinkler uniformity on corn field was lower than that on open field: When the CPSM operated at $100 \%$ speed, the sprinkler uniformities at the jointing and heading stages of corn were both significantly lower than those on the open field.

The future research will explore the promoting effect of sprinkler uniformity on the application of fertilizer or pesticide.

\section{ACKNOWLEDGMENT}

This paper was supported by National key research and development program of China (No.2016YFC0400104).

\section{REFERENCES}

[1] Zhou, X.J. (2019). Application of agricultural machinery automation technology to realize intelligent operation of agricultural machinery equipment. Agricultural Engineering Information. 39(36): 91-93. https://doi.org/10.16815/j.cnki.11-5436/s.2019.36.022

[2] Wang, Y.Z., Wang, A.M., Zhao, K., Song, L. (2019). Fast solution for deformation characteristics of flexible bearing of robot based on thin-walled ring theory. Transactions of the Chinese Society of Agricultural Engineering, $\quad 35(3)$ : 60-66. https://doi.org/10.11975/j.issn.1002-6819.2019.03.008

[3] Lang, J.B., Wang, J., Li, T.N., Wang, D.W. (2015). Requirements analysis of high efficiency water-saving irrigation equipment under background of water-saving and grain-increasing action in Heilongjiang Province. Journal of Drainage and Irrigation Machinery Engineering, 33(5): 456-460. https://doi.org/10.3969/j.issn.1674-8530.14.1030

[4] Mi, N., Zhang, Y.S., Cai, F., Ji, R.P., Liu, M., Yu, X.J. (2016). Research on water use efficiencies of maize and 
soybean in northeast China. Agricultural Research in the Arid Areas, 34(2): 1-8. https://doi.org/10.7606/j.issn.1000-7601.2016.02.01

[5] Jobbágy, J., Michlian, N., Dačanin, P., Rigó, I. (2019). Application and evaluation of performance quality of hose-reel irrigation machine. Acta Technologica Agriculturae, 22(4): 109-114 https://doi.org/10.2478/ata-2019-0020

[6] Prado, G.D. (2016). Water distribution from mediumsize sprinkler in solid set sprinkler systems. Revista Brasileira de Engenharia Agrícola e Ambiental, 20(3): 195-201. 1929/agriambi.v20n3p195-201

[7] Prado, G., Colombo, A., Barreto, A.C. (2019). Water distribution model for center pivot end gun sprinklers. Revista Brasileira de Engenharia Agrícola e Ambiental, 23(7): 477-483. https://doi.org/10.1590/18071929/agriambi.v23n7p477-483

[8] Yuan, S.Q., Ransford, O.D., Zhu, X.Y., Liu, J.P., Tian, K. (2017). Optimization of movable irrigation system and performance assessment of distribution uniformity under varying conditions. International Journal of Agricultural and Biological Engineering, 10(1): 72-79. https://doi.org/ 10.3965/j.ijabe.20171001.2293

[9] Zheng, J., Fan, J., Zhang, F., Yan, S., Xiang, Y. (2018). Rainfall partitioning into throughfall, stemflow and interception loss by maize canopy on the semi-arid Loess Plateau of China. Agricultural Water Management, 195: 25-36. https://doi.org/10.1016/j.agwat.2017.09.013

[10] Jiao, J., Su, D., Han, L., Wang, Y. (2016). A rainfall interception model for alfalfa canopy under simulated sprinkler irrigation. Water, 8(12): 585. https://doi.org/10.3390/w8120585

[11] Kermavnar, J., Vilhar, U. (2017). Canopy precipitation interception in urban forests in relation to stand structure. Urban Ecosystems, 20(6): 1373-1387. https://doi.org/10.1007/s1 1252-017-0689-7

[12] Ghilain, N., Arboleda, A., Barrios, J.M., GellensMeulenberghs, F. (2020). Water interception by canopies for remote sensing based evapotranspiration models. International Journal of Remote Sensing, 41(8): 29342945. https://doi.org/10.1080/01431161.2019.1698072

[13] Fan, Y., Meijide, A., Lawrence, D.M., Roupsard, O., Carlson, K.M., Chen, H.Y., Röll, A., Niu, F., Knohl, A. (2019). Reconciling canopy interception parameterization and rainfall forcing frequency in the Community Land Model for simulating evapotranspiration of rainforests and oil palm plantations in Indonesia. Journal of Advances in Modeling Earth Systems, 11(3): 732-751. https://doi.org/10.1029/2018MS001490

[14] Llorens, P., Domingo, F. (2007). Rainfall partitioning by vegetation under Mediterranean conditions. A review of studies in Europe. Journal of Hydrology, 335(1-2): 37-54. https://doi.org/10.1016/j.jhydrol.2006.10.032

[15] Fan, J., Oestergaard, K.T., Guyot, A., Lockington, D.A. (2014). Measuring and modeling rainfall interception losses by a native Banksia woodland and an exotic pine plantation in subtropical coastal Australia. Journal of hydrology, $\quad 515$ : https://doi.org/10.1016/j.jhydrol.2014.04.066

[16] Gómez, J.A., Giráldez, J.V., Fereres, E. (2001). Rainfall interception by olive trees in relation to leaf area. Agricultural Water Management, 49(1): 65-76. https://doi.org/10.1016/S0378-3774(00)00116-5

[17] Van Dijk, A.I.J.M., Bruijnzeel, L.A. (2001). Modelling rainfall interception by vegetation of variable density using an adapted analytical model. Part 1. Model description. Journal of Hydrology, 247(3-4): 230-238. https://doi.org/10.1016/S0022-1694(01)00392-4

[18] Li, W.C, Huang, X.Q., Gong, S.H., Wu, F., Fan, Y.S. (2003). Space distribution of sprinkler water under maize canopies. Transactions of the Chinese Society of Agricultural Engineering, 19(3): 59-62

[19] Li, J., Rao, M. (2000). Sprinkler water distributions as affected by winter wheat canopy. Irrigation Science, 20(1): 29-35. https://doi.org/10.1007/p100006715

[20] Kang, Y., Wang, Q.G., Liu, H.J., (2005). Winter wheat canopy-interception with its influence factors under sprinkler irrigation. Agricultural Water Management 74(3):

189-199. https://doi.org/10.1016/j.agwat.2004.11.004

[21] Liu, H.J., Zhang, R.H., Zhang, L.W., Wang, X.M., Li, Y., Huang, G.H. (2015). Stemflow of water on maize and its influencing factors. Agricultural Water Management, 158: 35-41. https://doi.org/10.1016/j.agwat.2015.04.013

[22] Wang, Q.G., Kang, Y.H., Liu, H.J., Liu, S.P. (2006). Method for measurement of canopy interception under sprinkler irrigation. Journal of Irrigation and Drainage Engineering, $132(2)$ : https://doi.org/10.1061/(asce)07339437(2006)132:2(185)

[23] Wang, D., Li, J.S., Rao, M.J. (2006). Sprinkler water distributions as affected by corn canopy. Transactions of the Chinese Society of Agricultural Engineering, 22(7): 43-47.

[24] Mauch, K.J., Delgado, J.A., Bausch, W.C., Barbarick, K., McMaster, G. (2008). New weighing method to measure shoot water interception. Journal of Irrigation and Drainage Engineering, 134(3): 349-355. https://doi.org/10.1061/(asce)07339437(2008)134:3(349)

[25] Liu, Y.L., Wang Q.J., Yang T., Lv, J.B., Zhao, G.X. (2015). Study on interception characteristics of different plants. Journal of Soil and Water Conservation, 29(3): 172-177.

[26] The Chinese National Standard. (2012). Agricultural irrigation equipment-Centre-pivot and moving lateral irrigation machines with sprayer or sprinkler nozzlesDetermination of uniformity of water distribution, GB/T19797-2012.

[27] Wang, Q.G., Kang Y.H., Liu H.J. (2005). Canopy interception and its dissipation of winter wheat. Agricultural Research in the Arid Areas, 23(1): 3-8. 